\title{
Study on Milk-Clotting Mechanism of Rennet-Like Enzyme from Glutinous Rice Wine: Proteolytic Property and the Cleavage Site on $\kappa$-Casein
}

\author{
T. Jiang, L. J. Chen, ${ }^{1}$ L. Xue, and L. S. Chen \\ Research and Development Center, Beijing Sanyuan Foods Co. Ltd., 100085, China
}

\begin{abstract}
Chinese Royal cheese, an ancient and attractive dairy product now in China, is made from milk coagulated with glutinous rice wine. In this paper, it was mainly studied on the proteolytic property toward proteins of bovine milk including caseins $(\mathrm{CN})$ and whey proteins and the cleavage bond on the $\kappa$-CN of rennet-like enzyme purified from glutinous rice wine by ion-exchange chromatography. Compared with whey protein, the rennet-like protease has substrate specificity toward $\mathrm{CN}$ but with different hydrolysis degrees among $\kappa_{-}, \alpha-$, and $\beta$-CN, and the $\alpha$-CN was almost completely degraded, whereas $\kappa$ - and $\beta$-CN partly showed hydrolysis in 12 $h$. The analysis for enzyme digestion by electrospray tandem mass spectrometry, Q-TOF2, and matrix-assisted laser desorption-ionization time-of-flight mass spectrometry revealed that the cleavage of protease from glutinous rice wine on $\kappa$-CN mainly happens at the $\mathrm{Thr}_{94}-\mathrm{Met}_{95}$ bond, which is different from the most chymosin-sensitive bond, Phe ${ }_{105}-$ Met $_{106}$.
\end{abstract}

Key words: proteolytic property, glutinous rice wine, rennet-like protease, casein

\section{INTRODUCTION}

Chinese Royal cheese, also called Gua-nai, is an oriental-style dairy product coagulated with glutinous rice wine, which is characterized by sweet, fruity, and slightly alcoholic flavor and soft curd appearance (Onyeneho et al., 1987). Traditionally, glutinous rice wine is made through fermentation by inoculating steamed glutinous rice with commercial starter (chiu-yao) or fungal cultures, and the filtrate liquid of glutinous rice wine, in which the rice is thrown away, has been used as both milk-clotting agents and flavoring agents to produce Gua-nai (Lin et al., 1997). Zhenmin and Chengxiang $(2000 a)$ reported that the milk-clotting of gluti-

Received February 15, 2007.

Accepted March 21, 2007.

${ }^{1}$ Corresponding author: chlj@263.net nous rice wine was a special process of chemical catalysts by rennet-like protease, an acid protease produced by molds of rice starter during glutinous rice fermentation. Therefore, the coagulation of Chinese Royal cheese is a kind of enzymatic coagulation. Rennet-like enzymes that come from Aspergillus and Rhizopus groups have been studied on purification, crystallization, and some enzymatic properties (Fukumoto et al., 1967; Iwasaki et al., 1967), and the organisms involved in the fermentation of glutinous rice have been isolated and identified (Guoxin et al., 1999; Zhenmin and Chengxiang, 2000b, 2001; Guoxin, 2005). However, no information is available on the substrate specificity and the comprehensive study comparing the hydrolysis toward CN components of milk-clotting protease from glutinous rice wine. The present research evaluated the proteolysis of bovine $\mathrm{CN}$, whey proteins by rennet-like protease purified from glutinous rice wine via ion-exchange resin, and the cleavage sites on $\kappa$-CN detected by mass spectrometry (MS) with an attempt to demonstrate the milk-clotting mechanism of glutinous rice wine.

\section{MATERIALS AND METHODS}

\section{Substrate}

Standard skim milk powder was dissolved in $0.2 \mathrm{~mol} /$ $\mathrm{L}$ acetate solution containing $0.03 \mathrm{~mol} / \mathrm{L} \mathrm{CaCl} \mathrm{CH}_{2}(\mathrm{pH}$ 6.5) at $10 \%$ (wt/vol). $\alpha$-, $\beta$-, and $\kappa$-Casein, $\beta$-LG, and albumin from bovine milk were from Sigma (St. Louis, MO). The substrates for proteolytic assays were prepared by dissolving $1.0 \mathrm{~g}$ of each type of protein separately in $100 \mathrm{~mL}$ of phosphate buffer $(100 \mathrm{mmol} / \mathrm{L}, \mathrm{pH} 6.5)$, and $\mathrm{NaN}_{3}$ was added to a final concentration of $0.1 \%$ (wt/ vol).

\section{Enzyme Preparation}

Preparation of Culture Liquid from Glutinous Rice Wine. The glutinous rice wine was made from steamed glutinous rice fermented with commercial chiu-yao (Q303, Guizhou Ligao LIRI Technologies Co. Ltd., Guizhou, China) for $7 \mathrm{~d}$ at $30^{\circ} \mathrm{C}$ and then allowed 
to stand for $4 \mathrm{~d}$ at $4^{\circ} \mathrm{C}$. The culture liquid $(200 \mathrm{~mL})$ from the wine was obtained by filtering through filter paper and centrifuging at $5,000 \times g$ for $5 \mathrm{~min}$.

Enzyme Purification. The crude enzyme was prepared by precipitating the culture liquid of the wine with 3 -fold $99.9 \%$ ethanol (vol $/ \mathrm{vol})$ at $4{ }^{\circ} \mathrm{C}$ overnight and centrifuging it at $12,000 \times g$ for $15 \mathrm{~min}$. The precipitate was then dissolved in $10 \mathrm{~mL}$ of $\mathrm{Na}$ phosphate buffer (100 mmol/L, $\mathrm{pH} 6.5$ ), and the resultant solution was applied to a DEAE-sephacel (Amersham Pharmacia Biotech, Piscataway, NJ) column $(1.0 \times 20 \mathrm{~cm})$ previously equilibrated with $100 \mathrm{mmol} / \mathrm{L} \mathrm{NaCl}$ in $50 \mathrm{mmol} / \mathrm{L} \mathrm{Na}$ phosphate buffer $(\mathrm{pH}$ 6.0). The proteins were eluted using a linear gradient of $\mathrm{NaCl}(0.1$ to $0.8 \mathrm{~mol} / \mathrm{L})$ at a flow rate of $30 \mathrm{~mL} / \mathrm{h}$ and collected in $4-\mathrm{mL}$ fractions. Fractions containing milk-clotting activity (MCA) were pooled and dialyzed using a dialysis membrane (Sigma) with a molecular weight cut off of $10 \mathrm{kDa}$ against distilled water at $4^{\circ} \mathrm{C}$ and the retentate was lyophilized. Then the freeze-dried enzyme was suspended in $5 \mathrm{~mL}$ of $\mathrm{Na}$ phosphate buffer $(100 \mathrm{mmol} / \mathrm{L}, \mathrm{pH} 6.5)$.

Assay of Enzyme Activity. The MCA was determined according to the method of Iwasaki et al. (1967). One Soxhlet unit of MCA was defined as the amount of enzyme required to clot $1 \mathrm{~mL}$ of milk (10\%, wt/vol) in $40 \mathrm{~min}$ at $35^{\circ} \mathrm{C}$. The proteolytic activity (PA) was detected with the modified method reported by Mohanty et al. (2003) with the substrate, $1.5 \%$ solution of bovine whole $\mathrm{CN}$ ( $\mathrm{pH} 6.0$ with $0.1 M$ phosphate buffer). The preheated substrate $(1 \mathrm{~mL})$ was mixed with 0.1 $\mathrm{mL}$ of purified enzyme solution, and the sample was incubated at $37^{\circ} \mathrm{C}$ for $60 \mathrm{~min}$, followed by the addition of $1 \mathrm{~mL}$ of $12 \%$ TCA. The optical density of soluble peptides was read at $280 \mathrm{~nm}$ with a UV-visible spectrophotometer (Cintra20, GBC Scientific Equipment Pty. Ltd., Dandenong, Victoria, Australia), and 1 unit of PA was defined as the amount of enzyme required to increase optical density $0.001 \mathrm{in} 1 \mathrm{~min}$. In the following substrate specificity experiments, the prepared protease solution was adjusted to MCA of 26.7 Soxhlet units/ $\mathrm{mL}$, corresponding to a milk-clotting time of $15 \mathrm{~min}$.

\section{Analysis of Substrate Specificity}

Protein hydrolysis was carried out in a mixture of enzyme and substrate with a ratio of $1: 50(\mathrm{vol} / \mathrm{vol})$ at $37^{\circ} \mathrm{C}$ in a thermostated water bath for $1 \mathrm{~h}$. The reaction was terminated by adding an equal volume of doublefold sample buffer containing mercaptoethanol (5\%) and urea $(6 \mathrm{~mol} / \mathrm{L})$ to inactivate the enzyme and unfold the protein. To determine the optimal substrate, the hydrolysates were analyzed by 15\% SDS-PAGE using a Mini Protein system (Bio-Rad Laboratories, Watford,
UK) according to the instructions of the manufacturer (Bio-Rad Laboratories).

\section{Analysis of CN Hydrolysates}

Solutions $(0.5 \% \mathrm{wt} / \mathrm{vol})$ of CN components were prepared by diluting the corresponding substrates (1\% wt/ vol) with the Na phosphate buffer $(100 \mathrm{mmol} / \mathrm{L}, \mathrm{pH} 6.5)$. The purified enzyme $(0.1 \mathrm{~mL})$ was then added to $5 \mathrm{~mL}$ of $\mathrm{CN}$, and the mixtures were held at $37^{\circ} \mathrm{C}$. Samples $(0.5 \mathrm{~mL})$ were taken at $5,15,30,60,120,180$, and 240 min and $12 \mathrm{~h}$, respectively, and the reaction was also stopped by being mixed with the sample buffer described in Analysis of Substrate Specificity. The degradation of purified enzyme to different $\mathrm{CN}$ components was analyzed by using the modified Laemmli polypeptide fractioning gel system (Ausubel et al., 1995), which was performed under reducing conditions with $20 \%$ acrylamide gels (Sigma), and the gels were stained with Coomassie Brilliant Blue G-250, followed by destaining with $20 \%$ methanol.

\section{Mass Spectrometry Analysis of the Cleavage Site on $\kappa-C N$}

Bovine $\kappa$-CN $(0.5 \% \mathrm{vol} / \mathrm{vol})$ was digested with purified protease for $15 \mathrm{~min}$, corresponding to the milk-clotting time. The enzyme digestion was immediately desalted at $4^{\circ} \mathrm{C}$ by UF tube (4420, Millipore Corp., Bedford, MA) with $3 \mathrm{kDa}$ of molecular weight cut off and pooled directly for electrospray tandem mass spectrometry (QTOF2, Micromass, Manchester, UK) and matrix-assisted laser desorption-ionization time-of-flight mass spectrometry (MALDI-TOF-MS; Reflex, Bruker, Billerica, MA) to determine the exact molecular weight of peptide fractions. In addition, the hydrolysate was fractioned by PAGE, and a band corresponding with the molecular weight of $\sim 14 \mathrm{kDa}$ was excised for ingel trypsin digestion and analysis via MALDI-TOF-MS (Autoflex, Bruker). On the other hand, MALDI-TOFMS (Reflex, Bruker) was also applied to the intact $\kappa$-CN.

\section{RESULTS}

\section{Enzyme Property}

It is shown in Table 1 that the specific milk-clotting activities of extracts increased more than the PA during purification. Among the 3 kinds of purification, anionexchange chromatography gave the highest ratio of MCA:PA, 6.7, which showed the enzyme was a kind of rennet-like enzyme. As shown in Figure 1 (lanes 2 and 3 ), the enzyme was a protein corresponding to the molecular weight of standard $36.0 \mathrm{kDa}$. And it was sug- 
Table 1. Purification and enzymatic assays of extracts from glutinous rice wine

\begin{tabular}{|c|c|c|c|c|c|c|c|c|c|c|}
\hline $\begin{array}{l}\text { Purification } \\
\text { step }\end{array}$ & $\begin{array}{l}\text { Volume } \\
\text { (mL) }\end{array}$ & $\begin{array}{l}\text { Milk-clotting } \\
\text { activity } \\
\text { (Soxhlet } \\
\text { units/mL) }\end{array}$ & $\begin{array}{c}\text { Total } \\
\text { Soxhlet } \\
\text { units }\end{array}$ & $\begin{array}{c}\text { Recovery } \\
(\%)\end{array}$ & $\begin{array}{l}\text { Protein } \\
(\mathrm{mg} / \mathrm{mL})\end{array}$ & $\begin{array}{l}\text { Total } \\
\text { protein } \\
(\mathrm{mg})\end{array}$ & $\begin{array}{c}\text { Specific } \\
\text { activity } \\
\text { (Soxhlet } \\
\text { units } / \mathrm{mg} \text { ) }\end{array}$ & $\begin{array}{l}\text { Relative } \\
\text { purification } \\
\text { fold }\end{array}$ & $\begin{array}{l}\text { Proteolytic } \\
\text { activity } \\
\text { (U/mg) }\end{array}$ & $\begin{array}{c}\text { Milk-clotting } \\
\text { activity: } \\
\text { proteolytic } \\
\text { activity }\end{array}$ \\
\hline Filtrates & 200 & 7.79 & 1,558 & 100 & 65.7 & 13.140 & 0.12 & 1.0 & 0.03 & 1.67 \\
\hline Crude enzyme & 10 & 150 & 1,500 & 96.3 & 28.9 & 289 & 5.19 & 43.25 & 0.37 & 5.62 \\
\hline Purified enzyme & 5 & 200 & 1,000 & 64.2 & 6.2 & 31 & 32.26 & 268.83 & 1.92 & 6.70 \\
\hline
\end{tabular}

gested that the purified protein might be homogeneous in nature, as shown by the presence of 1 band (lane 3 ).

\section{Characterization of Substrate Hydrolysis}

The CN components and whey proteins were hydrolyzed by the rennet-like protease purified from glutinous rice wine with remarkable differences in the degree of hydrolysis (Figure 2). It was suggested that CN were hydrolyzed specifically, whereas whey protein, $\beta$ $\mathrm{LG}$, and albumin were hydrolyzed very little. It was also shown that the purified enzyme had different degrees of hydrolysis toward different $\mathrm{CN}$ components.

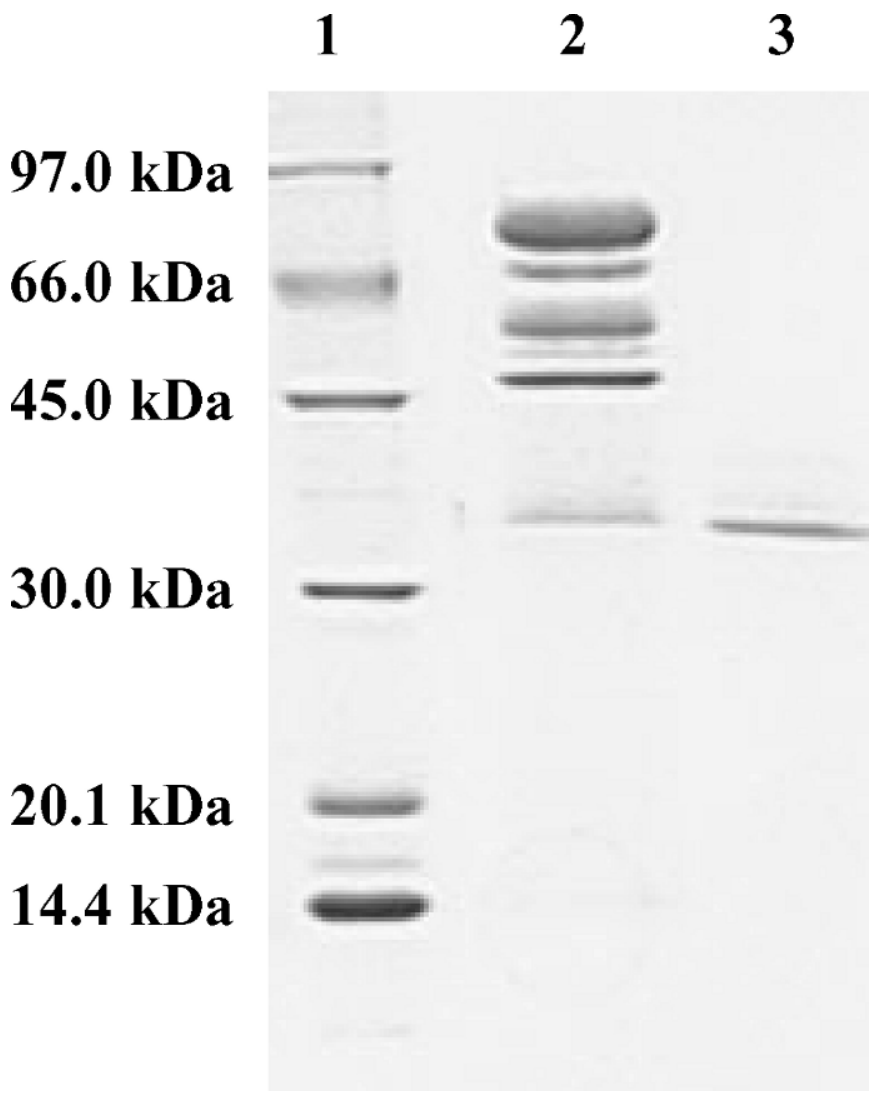

Figure 1. The SDS-PAGE (15\%) profile of purified enzyme from glutinous rice wine. Lane 1 = protein molecular weight markers; line 2 = crude enzyme; lane 3 = purified enzyme.
To further investigate the proteolytic properties of purified enzyme, the time course of CN components hydrolysis was analyzed by peptide PAGE electrophoretograph, which is shown in Figure 3a to 3c. As expected, the degree of hydrolysis of proteins was different from one other, and the $\alpha$-CN exhibited a higher hydrolysis degree than others during the test times. From the main peptide bands shown by the arrow in Figure 3 , the degree of hydrolysis varied with times; $\alpha$ - and $\beta$ $\mathrm{CN}$ were degraded increasingly from $5 \mathrm{~min}$ to $12 \mathrm{~h}$, and $\alpha$-CN was almost completely hydrolyzed, whereas $\beta$ $\mathrm{CN}$ showed only partial degradation in $12 \mathrm{~h}$ (Figure 3a and $3 \mathrm{~b}$ ). However, most of the $\kappa$-CN was hydrolyzed during the first $15 \mathrm{~min}$ and then degraded very little in the following reaction (Figure 3c).

\section{Cleavage Site of the Rennet-Like Enzyme on $\kappa-C N$}

It is well-established that rennet catalyzes the hydrolysis of a susceptible Phe-Met bond in $\kappa$-CN in the mechanism of rennet-induced coagulation of milk. However, the milk-clotting mechanism of protease from Cryphonectria parasitica seems to result from its specific action on $\mathrm{Ser}_{104}-\mathrm{Phe}_{105}$ in $\kappa$-CN (Garg and Johri, 1994). To determine the cleavage site of the rennet-like protease from glutinous rice wine, the enzyme hydrolysate of $\kappa$ $\mathrm{CN}$ was subjected to mass spectrometry analysis. First, the moleculer weight of peptide fragments was analyzed by ESI-MS, Q-TOF2, and MALDI-TOF-MS (Reflex, Bruker). As shown in Figure 4, distinct peptides were detected in the sample originating from the digestion mixture with a mass spectrum characterized by the presence of an array of signals in the range from $6,600 \sim 7,000$ at mass or mass:charge ratio $(\mathbf{m} / \boldsymbol{z})$. The molecular mass of the largest major peptide determined by Q-TOF2 was 6,786.90, which was in accordance with the calculated mass of 6,786.47 of fragment that correspond to $\mathrm{Tyr}_{25}-\mathrm{Thr}_{94}$ of $\kappa$-CN (GenBank number NP776719), and the second highest peak of 6,755.10 was in agreement with the AA backbone molecular weight $(6,674.52)$ of $\mathrm{Met}_{95}-\mathrm{Pro}_{156}$ plus the mass of 1 phosphate group (90.5; Figure 4a, and Figure 5). It also showed a minor series of peaks at masses of $6,675.30,6,676.40$, $6,834.90$, and $6,873.00$, which were consistent with the formation of AA backbone (Met ${ }_{95}-\mathrm{Pro}_{156}$ and $\mathrm{Tyr}_{25}-\mathrm{Thr}_{94}$ 


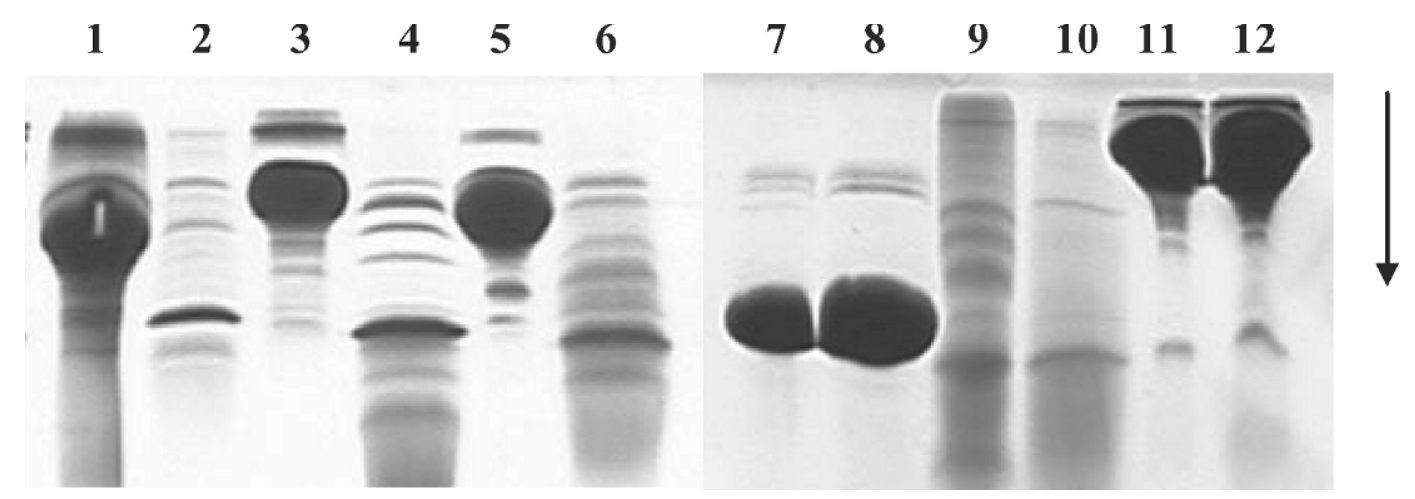

Figure 2. The SDS-PAGE electrophoregrams of bovine milk proteins hydrolyzed by protease of glutinous rice wine. Lanes $1,3,5,7,9$, and 11 show the intact $\kappa-, \beta$-, and $\alpha$-CN; $\beta$-LG; whole $\mathrm{CN}$; and albumin $(10 \mathrm{mg} / \mathrm{mL})$, respectively, and the corresponding digested is shown in lanes $2,4,6,8,10$, and 12 . The direction of migration is shown with an arrow.

a

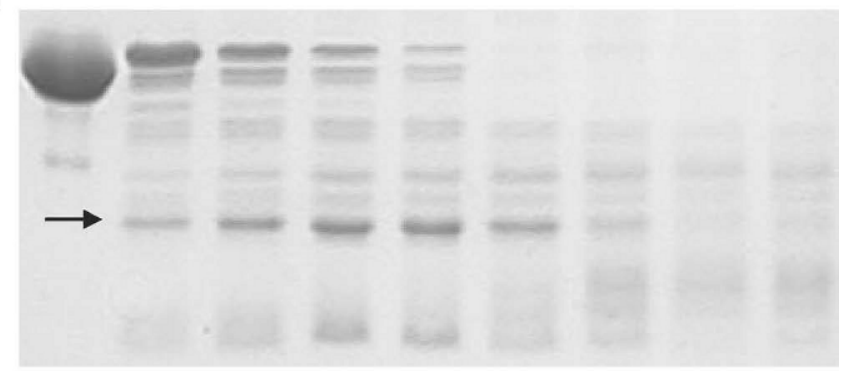

$\mathbf{b}$

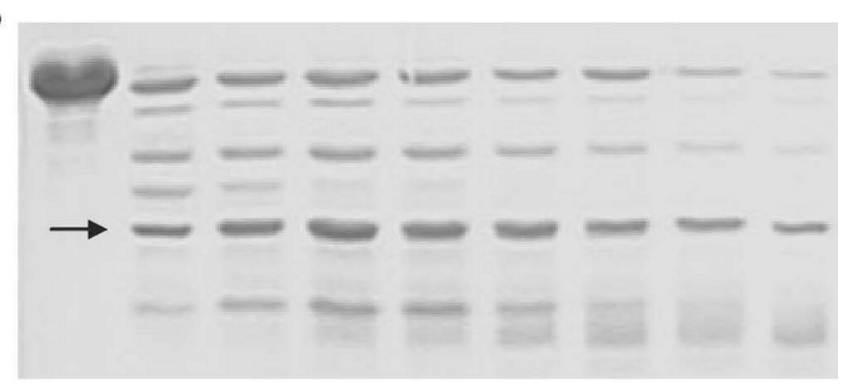

c

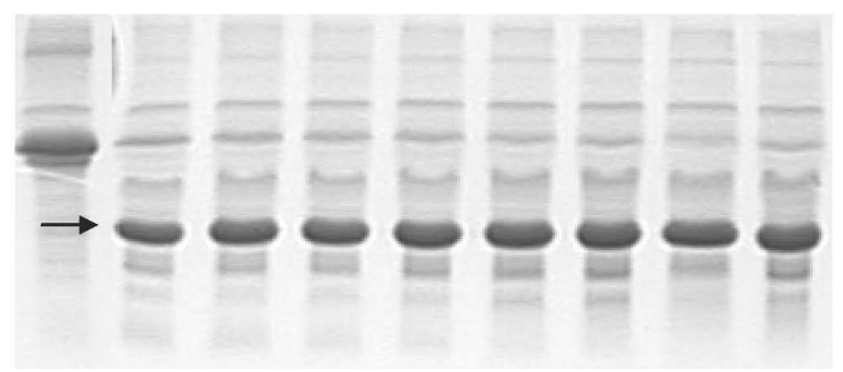

Figure 3. Peptide PAGE electrophoregrams of CN compositions by rennet-like protease from glutinous rice wine at reaction times 0 , $5,15,30,60,120,180$, and $240 \mathrm{~min}$ and $12 \mathrm{~h}$ (left to right). The main peptide is indicated with an arrow; $\mathrm{a}=\alpha-\mathrm{CN} ; \mathrm{b}=\beta-\mathrm{CN} ; \mathrm{c}=\kappa-\mathrm{CN}$. of $\kappa$-CN, respectively) with zero or 1 to 2 phosphate groups. Peaks with $m / z$ higher than 13,000 and below 6,000 were also observed by MALDI-TOF-MS (Reflex, Bruker), in addition to the signals corresponding to the mass observed in Q-TOF2 (Figure 4b and 4c). At the same time, the intact $\kappa$-CN was also analyzed by MALDI-TOF-MS (Reflex, Bruker, data not shown) and compared with the results of rennet digested. Thus, the analysis on MS data was highly suggestive that there should be a multicleavage site of the rennet-like enzyme from glutinous rice wine toward bovine $\kappa$-CN, but the bond between $\mathrm{Thr}_{94}$ to Met $_{95}$ was the major cleavage site.

Second, to further identify the cleavage bond, an ingel protease digestion and peptide mass fingerprint were performed by MALDI-TOF-MS (Autoflex, Bruker) for a peptide that corresponded to the band shown with an arrow in Figure 3c. The MALDI-TOF-MS and analysis results are shown in Figure 5 and Table 2, and a diagram of the sequence coverage of $\kappa$-CN by MALDITOF-MS (Autoflex, Bruker) is also shown (Figure 6). About $88.3 \%$ (the underlined sequence in Figure 6) of the $\mathrm{N}$-terminal sequence of $\kappa$-CN was covered by the in-gel digested band, a peptide that matches the fragment at a mass of $6,786.90$ or $\mathrm{m} / z$ of $6,600 \sim 6,800$ in Figure $4 \mathrm{a}$ and $4 \mathrm{~b}$. Taken all of the above-mentioned together, it can be concluded that the cleavage site of purified rennet-like protease in this study on bovine $\kappa$ CN happened mainly at the $\mathrm{Thr}_{94}-\mathrm{Met}_{95}$, a new cleavage bond that has not been reported for chymosin and rennet substitute.

\section{DISCUSSION}

The milk-clotting properties of rennet-like protease from chiu-yao, a fermentation starter of glutinous rice 
a

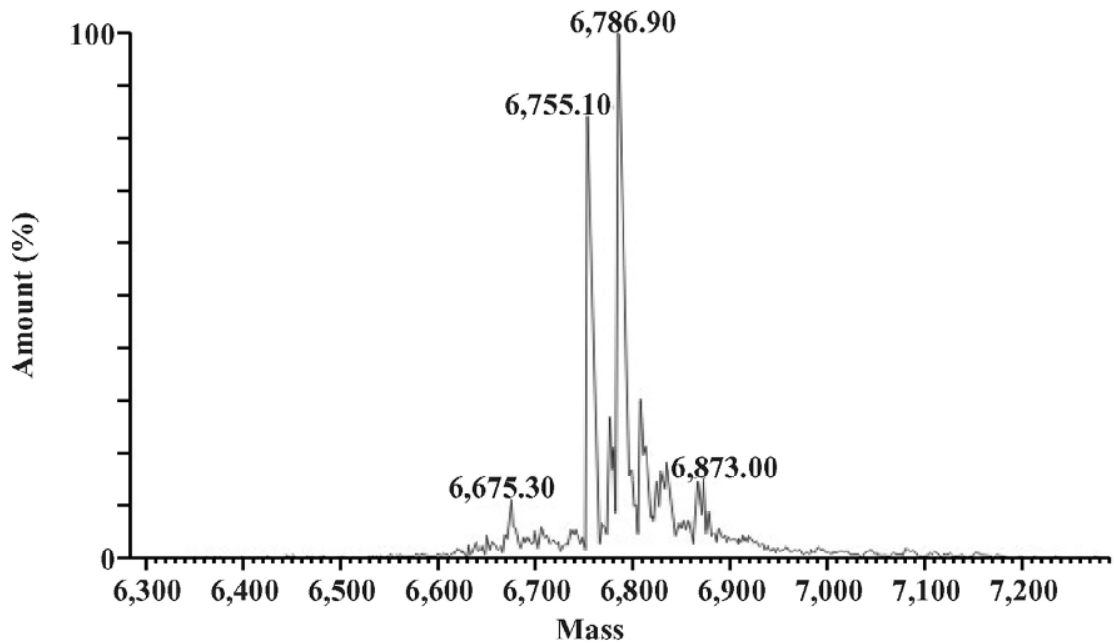

b

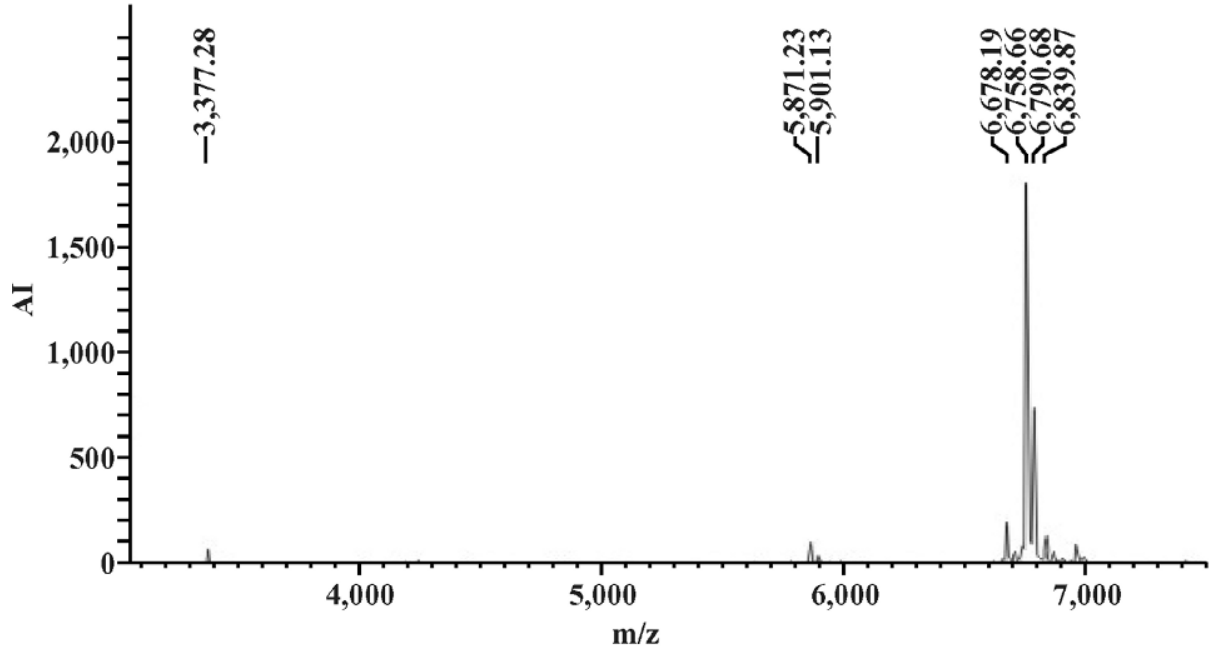

c

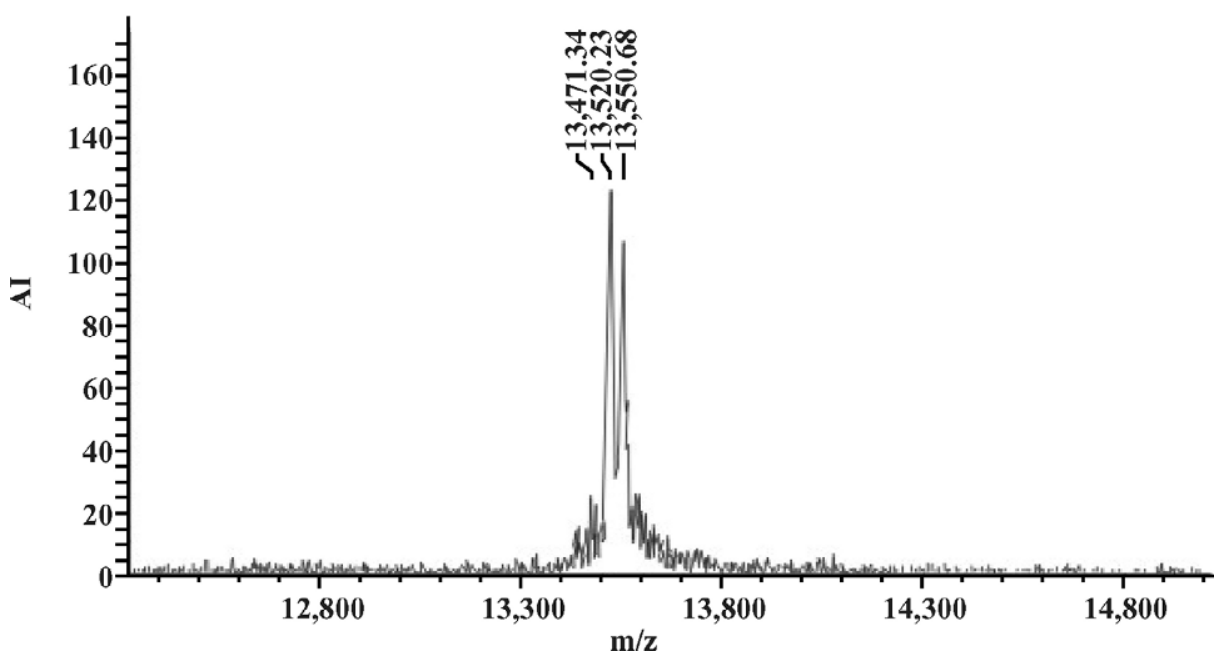

Figure 4. Mass spectrum of the rennet digestion of bovine $\kappa$-CN. a = electrospray tandem mass spectrometry, Q-TOF2; $\mathrm{b}$ and $\mathrm{c}=$ matrixassisted laser desorption-ionization time-of-flight mass spectrometry (Reflex, Bruker, Billerica, MA). $\mathrm{m} / z=$ mass:charge ratio; $\mathrm{AI}=$ abundance of ion. 


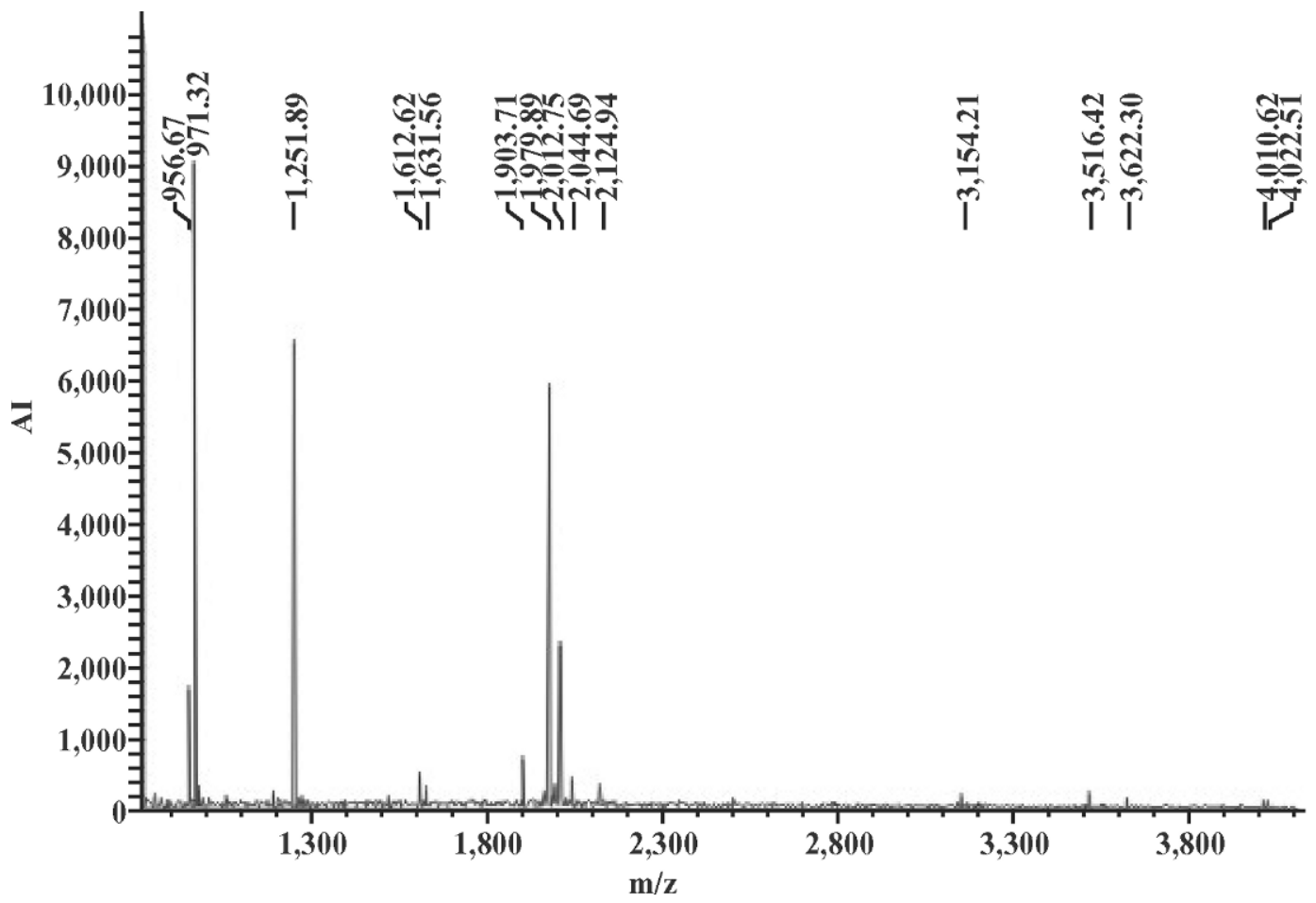

Figure 5. Peptide mass fingerprint of $\kappa$-CN fragment from in-gel trypsin digestion. $m / z=$ mass:charge ratio; $A I=$ abundance of ion.

wine, have been described by Guoxin (2005). The extracts from glutinous rice wine in this study had increasing activity during the process of purification, although there was a drastic reduction in protein recovery (Table 1). The refined rennet had a molecular weight of $36.0 \mathrm{kDa}$ with electrophoretic homogeneity (Figure 1) and exhibited higher specific MCA and lower PA, with the ratio being 6.7 (Table 1), which was especially important for cheese-making. It confirmed the fact that in making Chinese Royal cheese, milk coagulation is attributed to the rennet-like enzyme (Zhenmin and Chengxiang, 2000a).
Considering these processes of $\mathrm{CN}$ and whey protein hydrolysis, differences were observed in the substrate specificity of the protease (Figures 2 and 3). It demonstrated that $\mathrm{CN}$ showed much more selectivity than $\beta$ LG and albumin. In other words, the rennet-like enzyme purified from glutinous rice wine had caseinolytic specificity. In addition to cleaving the $\kappa$-CN, chymosin and rennet-like enzymes, especially the microbial rennet, also readily hydrolyze certain peptide bonds in $\alpha$ and $\beta$-CN, but the phosphoramide bonds of $\alpha$ - and $\beta$-CN are hydrolyzed slowly (Garg and Johri, 1994; Krause et al., 1998). However, the degree of hydrolysis of milk-

Table 2. Assignment of fragment ions obtained from matrix-assisted laser desorption-ionization time-offlight mass spectrometry ${ }^{1}$ (Autoflex, Bruker) of the in-gel trypsin digestion of peptide from $\kappa$-CN

\begin{tabular}{lccl}
\hline & {$[\mathrm{M}+\mathrm{H}]^{+}$} & & \\
$\begin{array}{l}\text { Measured } \\
\text { mass }\end{array}$ & $\begin{array}{c}\text { Calculated } \\
\text { mass }\end{array}$ & \multicolumn{1}{c}{$\begin{array}{l}\text { Sites in } \\
\kappa \text {-CN }\end{array}$} & \multicolumn{1}{c}{ Sequence } \\
\hline 956.67 & 956.32 & 17 to 24 & FFSDKIAK \\
$1,630.56$ & $1,630.76$ & 1 to 13 & QEQNQEQPIRCEK \\
$1,251.59$ & $1,251.71$ & 25 to 34 & YIPIQYVLSR \\
$1,979.89$ & $1,980.89$ & 69 to 86 & SPAQILQWQVLSNTVPAK \\
$4,010.62$ & $4,010.06$ & 35 to 68 & YPSYGLNYYQRPVALINNQFLPYPYYAK \\
& & & PAAVR \\
\hline
\end{tabular}

${ }^{1}$ Autoflex, Bruker, Billerica, MA. $[\mathrm{M}+\mathrm{H}]^{+}=$molecule and proton with 1 positive charge. 
QEQNQEQP I RCEKDERF FS DK IAKY I P I QYVLSRY P SY

GLNYYQQKPVALI NNQFLPYPYYAKPAAVRSPAQI LQW

QVLS NTVPAKSCQAQPTT MARHPHPHL S FMAI PP KKNQ

\section{DKTE I PT I NT I ASGEPT ST PT T EAVESTVAT LEDS PEV}

\section{E S P PE I NTVQVT STAV}

Figure 6. Amino acid sequence of $\kappa$ - $\mathrm{CN}$ and peptide fragments detected by electrospray tandem mass spectrometry, Q-TOF2 (shaded and boxed), and matrix-assisted laser desorption-ionization time-offlight mass spectrometry (underlined; Autoflex, Bruker, Billerica, MA).

clotting enzyme from glutinous rice wine was significantly different from chymosin or pepsin toward $\kappa$-CN and the $\alpha$ - and $\beta$-CN. It showed that $\mathrm{CN}$ had different rates of hydrolysis at the primary phase of milk clot, with a higher degree of hydrolysis on $\kappa$-CN than $\alpha$ - and $\beta$-CN (Figure 3, lanes 2 and 3). The degradation of $\alpha$ and $\beta$-CN was higher than $\kappa$-CN, and $\alpha$-CN had a nearly complete breakdown after a 12 -h reaction (Figure 3, lanes 5 to 9 ), which clearly revealed that, among $\kappa-, \alpha-$, and $\beta$-CN, the observed protease in this study had little specificity. Although the change in cheese properties during ripening and storage is related to the combined effects of hydrolysis of $\alpha$ - and $\beta$-CN, many bitter peptides that are essential to the flavor were found originating from $\alpha$ - and $\beta$-CN (Singh et al., 2005).

It was reported that the $\kappa$-CN had to be subjected to proteolysis from 80 to $90 \%$ before appreciable aggregation and clotting could occur, whereas reducing the $\mathrm{pH}$ to about 6.6 or increasing the temperature above $30 \sim 32^{\circ} \mathrm{C}$ permits coagulation at a lower degree of $\kappa$ $\mathrm{CN}$ hydrolysis, and approximately $65 \%$ hydrolysis is required to induce flocculation at $35^{\circ} \mathrm{C}$ (Garg and Johri, 1994; Krayushkin et al., 2003). The hydrolysis degree has not been detected, but a similar conclusion should be predicted from the time course of degradation in this study. As shown in Figure 3c, the most $\kappa$-CN was degraded at the reaction time of $15 \mathrm{~min}$, a time of milk aggregation.

It has also been reported that porcine pepsin A and $\mathrm{C}$ and Rhizomucor miehei proteinase cleave the same bond as chymosin [i.e., the peptide bond 105-106 between Phe and Met, a sensitive bond to chymosin (Garg and Johri, 1994)]. And there has been some evidence to suggest that rennet-like enzymes from other sources hydrolyze the CN at other bonds than $\mathrm{Phe}_{105}-\mathrm{Met}_{106}$, such as proteases from Endothia parasitica and Cryphonectria parasitica, which act on $\mathrm{Ser}_{104}-\mathrm{Phe}_{105}$ (Drohse and Foltmann, 1989; Garg and Johri, 1994), whereas the hydrolysis of $\mathrm{CN}$ by acid protease at the bond of $\mathrm{Thr}_{94}-\mathrm{Met}_{95}$ has not been reported so far. The results obtained from Q-TOF2 and MALDI-TOF-MS (Figures 4 to 6 and Table 2) revealed that the major cleavage of the protease from glutinous rice wine on $\kappa$ $\mathrm{CN}$ is at the $\mathrm{Thr}_{94}-\mathrm{Met}_{95}$ bond, which is different from the most sensitive bond, $\mathrm{Phe}_{105}-\mathrm{Met}_{106}$ to chymosin. And the peaks with $m / z$ higher than 13,000 and below 6,000 , as shown in Figure $4 \mathrm{~b}$ and $4 \mathrm{c}$, revealed that there was more than one cleavage site as well. The results further suggest that rennet-like enzymes have other susceptive bonds of hydrolysis in $\kappa$-CN and provide some new indications about the mechanism of rennet on $\mathrm{CN}$.

\section{CONCLUSIONS}

Milk-clotting enzymes purified from glutinous rice wine exhibited significant caseinolytic activity toward bovine $\mathrm{CN}$ compared with whey protein $\beta$-LG and albumin but no highly specific hydrolysis among $\kappa$-CN and other CN components. From the experiments, it was suggested that the initial reaction toward $\kappa$-CN was mainly splitting of the bond between $\mathrm{Thr}_{94}-\mathrm{Met}_{95}$, which further demonstrated the milk-clotting mechanism of glutinous rice wine.

\section{ACKNOWLEDGMENTS}

This work was financially supported by the Research and Development Program of China (2001BA501A12) from the National Department of Science and Technology.

\section{REFERENCES}

Ausubel, F. M., R. Brent, R. E. Kingston, D. D. Moore, J. G. Seidman, J. A. Smith, and K. Struhl. 1995. Short Protocols in Molecular Biology. 3rd ed. John Wiley \& Sons Inc., New York, NY.

Drohse, H. B., and B. Foltmann. 1989. Specificity of milk-clotting enzymes towards bovine $\kappa$-casein. Biochim. Biophys. Acta 995:221-224.

Fukumoto, J., D. Tsuru, and T. Yamamoto. 1967. Studies on mold protease. I. Purification, crystallization and some enzymatic properties of acid protease of Rhizopus chinensis. Agric. Biol. Chem. 31:710-717.

Garg, S. K., and B. N. Johri. 1994. Rennet: Current trends and future research. Food Rev. Int. 10:313-355.

Guoxin, T. 2005. Characteristics of Rhizopus milk-clotting enzyme in jiu-yao and studies on texture of kou wan lao. PhD Thesis. China Agric. Univ., Beijing.

Guoxin, T., Q. Qingyang, W. Yulin, S. Lipin, Z. Zhiwu, and Z. Liebing. 1999. The microbiology of guan-nai. Sci. Technol. Food Indust. 8:34-38. (In Chinese)

Iwasaki, S., G. Tamura, and K. Arima. 1967. Milk clotting enzyme from microorganisms. II. The enzyme production and the properties of crude enzyme. Agric. Biol. Chem. 31:546-551.

Krause, W., M. Partzsch, Z. M. Hassan, and T. Haufe. 1998. Substrate and binding specificity of aspartic proteases with milk clotting properties. Nahrung 42:162-165.

Krayushkin V. A., Y. Sviridenko, G. V. Murunova, and V. N. Krayushkina. 2003. On mechanism of rennet clotting of milk. Milchwissenschaft 58:531-535. 
Lin, C.-W., R.-C. Yu, H.-L. Chen, and S.-L. Chen. 1997. Culture filtrates from a fermented rice product (lao-chao) and their effects on milk curd firmness. J. Food. Sci. 62:1080-1082.

Mohanty, A. K., U. K. Mukhopadhyay, J. K. Kaushik, S. Grover, and V. K. Batish. 2003. Isolation, purification and characterization of chymosin from riverine buffalo (Bubalos bubalis). J. Dairy Res. 70:37-43.

Onyeneho, S. N., J. A. Partridge, J. R. Brunner, and J. Guan. 1987. Manufacture and characterization of Gua-nai: A new dairy food produced with an oriental-type culture. J. Dairy Sci. 70:24992503.
Singh, T. K., N. D. Young, M. Drake, and K. R. Cadwallader. 2005. Production and sensory characterization of a bitter peptide from $\beta$-casein. J. Agric. Food Chem. 53:1185-1189.

Zhenmin, L. and L. Chengxiang. 2000a. Studies on milk-clotting mechanism of glutinous rice wine. Food Sci. 21:13-15.

Zhenmin, L., and L. Chengxiang. 2000b. Studies on microbacteria of glutinous rice wine. Agric. Prod. Dev. 3:14-16.

Zhenmin, L., L. Hui, and L. Chengxiang. 2001. Studies on the screening of rennet producing strain and its culture conditions. Food Fermentation Ind. 27:8-11. 